One is bound reluctantly to regret that this book, while going farther and deeper than its predecessors, should not at the same time have preserved all their merits. In fact, it is the case that the first volume of Enriques-Campedelli (now long unobtainable) is still by far the best introduction to the subject, as well as being an extraordinary illustration of didactic skill : in some ways, of course, it must have been easier to write. In another respect, moreover, the more elementary work has a decided advantage over the treatise; for the account of double planes given in the latter is really inadequate unless the reader is assumed to have previous knowledge of the matter under discussion.

But with these reservations one can have nothing but praise for the book; written with all the author's characteristic lucidity, it takes us, in its eleven chapters, from the first notions of birational geometry on $a_{\text {s }}$ surface (the foundations of which were laid by Enriques himself when scarcely more than a student) to the classification of surfaces by means of their genera and plurigenera, which is one of his most striking discoveries. On this long road we encounter not only the topics which must perforce find a place, but also fascinating details of lesser importance, the whole adorned, as is Enriques's invariable custom, by historical notes at every stage. The treatise, which is exceedingly well printed, is indispensable to any mathematical library and will for long remain a monument to its author's memory. As though to complete the picture of what must be considered the crowning glory of Italian geometry, there is an interesting preface by Senator G. Castelnuovo, who was Enriques's collaborator in its creation.

L. ROTH

\section{CAUSATION OF MENTAL DEFICIENCY}

The Biology of Mental Defect

By Dr. Lionel S. Penrose. Pp. xiv $+285+7$ plates. (London: Sidgwick and Jackson, Ltd., 1949.) 21s. net.

$\mathrm{T}$

HIS is an excellent book, although by no means an easy one to read for those unequipped with a knowledge of statistics and genetics. Nevertheless, it is, even for those, a rewarding one. Prof. L. S. Penrose, who is Galton professor of eugenics at University College, London, has made genetics his chosen study and is well known for his work in this field. His previous publications have been on mental deficiency and heredity. This present book is not a text-book but a general discussion on mental deficiency from the broadest possible point of view.

Although most of the book is devoted to the genetic side, there are chapters on the historical background and the incidence and nature of deficiency, as well as the principles of classification. The author's point of view is a relief from the older type of text-book in which uncertainties dogmatically stated have been copied from still older 'authorities'. Prof. Penrose goes consistently to the recent original publications, and almost every chapter gives new facets suggestive of fresh areas for research; and, indeed, the worker in mental deficiency will find this book well worth reading for the indications of fields which have not yet been worked.
Naturally, many of the old fallacies, which were the foundations of the older text-books, are shaken by statistics which appear incontrovertible. An example of this is the dearly loved theory of 'blastophoria', or damage to the germ-plasm by alcohol or other poisons. Prof. Penrose points out that the Colchester Survey showed that the children of alcoholics were to be found no less numerous and no more defective than the children of non-alcoholic parents of similar mental grades. Another theory, so strongly supported by Mott in the early years of this century, was that of 'anticipation', which was that the germ-plasm once vitiated showed a tendency to degenerate over a long period. The author deals this theory a sharp blow by stating decisively that "the main difficulty in accepting the hypothesis of anticipation is its total lack of support from observations in the field of animal genetics".

Prof. Penrose is most interesting in discussing causation in his own field, and he deals in a masterly fashion with the problems of mutation, rare dominant and recessive genes, additive genes, sex-linked genes and so on. However, he has by no means a closed mind on the influence of environment, and quotes work by Freeman, Hozinger and Mitchell on the intelligence of children placed in foster homes and the "significant tendency to develop resemblance to the foster parents, both in mental level and in behaviour". These findings seem to have been supported by the work of Burks and of Wellman. As Prof. Penrose points out, the results show that "the post-natal environment can contain decisive psychological factors tending to cause or prevent the development of mental defect". This is one of the valuable suggestions for research which the author makes and, if confirmed, might have tremendous effect on our treatment of the defective. It suggests that the child born in a defective home should be removed as soon as possible before this stultifying effect of the parents inhibits its mental development.

The book does not deal entirely with genetically determined mental deficiency, but a chapter is devoted to defects of obscure origin and those due to environment. Everywhere Prof. Penrose shows his judgment by cautiously weighing up the evidence and, if the causal factors are not clear, pointing out the various possibilities. Even such matters as gonadal degeneration in schizophrenia, which has been looked at sceptically in recent times, he considers worthy of investigation in dementia præcocissima.

Since mental deficiency is usually an unhopeful illness to treat, not a great deal of the book is devoted to therapy; but such help as can be given to the patient is suggested. Valuable notes are recorded on eugenic prognosis, preventive treatment and psychological training. There are twenty-three pages of references and ten appendixes. The index is the most unsatisfactory part of the book, and it is not easy to discover page references from it. For example, there is no mention of "Blastophoria" under B, but it is concealed under "Germ Plasm Injury"; and again "Incest" is not under I, but only under "Consanguinity". These cause an irritating delay when one wishes to re-discover some fact noted in reading. However, these are very minor faults, and perhaps to amplify the index would have made it too un. wieldly. The production of the work is excellent: the printing is on good paper, and the dark-blue binding is suitable for a scientific bookshelf.

Cutfrord Allen 